\title{
Application of satellite altimetry in understanding river-wetland flow interactions of Kosi river
}

\author{
V Chembolu ${ }^{1}$, A K Duber ${ }^{2, *}$, P K Gupta ${ }^{2}$, S Dutta ${ }^{1}$ and R P Singh ${ }^{2}$ \\ ${ }^{1}$ Indian Institute of Technology Guwahati, Kamrup District, Guwahati 781 039, India. \\ ${ }^{2}$ Space Applications Centre (ISRO), Jodhpur Tekra, Ahmedabad 380 015, India. \\ *Corresponding author. e-mail: a_dubey@sac.isro.gov.in
}

MS received 2 February 2018; revised 18 July 2018; accepted 21 July 2018; published online 27 March 2019

Flood-plain wetlands are the seasonal water bodies formed along a river. These wetlands become active during the monsoon season, which frequently grow in size with seasonal floods and eventually dry up during the non-monsoon season. The flow interaction between flood-plain wetlands and the river sometimes vary over a very short period in response to rapid rise in the river water level due to high precipitation in its upstream catchment. Understanding the complex flow interactions between the river and its associated flood-plain wetlands with field-based measurements of wetland hydrologic characteristics is always a challenging task. To overcome these challenges, an attempt has been made to utilise Topex/Poseidon satellite altimetry-derived water levels into a hydrodynamic model (HECRAS) to study river and wetland flow interactions in the lower reach of the Kosi river in India. The satellite altimetry-derived water levels and Landsat satellite images on the Kosi wetlands are used to develop volume-elevation relation. HEC-RAS is setup over the study area and calibrated for different values of manning's roughness coefficient $(n)$ for the river bank and the main channel of the river for the period of 1993-1996. Unsteady flow simulations are carried out for different monsoon seasons to simulate daily river flow interaction (inflow/outflow) between river and wetlands. Statistical analysis is performed between the altimetry-derived and the model-simulated water levels. It is found that simulated water levels are in good agreement $\left(R^{2}=0.87\right.$, root mean square error of $0.84 \mathrm{~m}$ and Nash-Sutcliffe efficiency coefficient of 0.85 ) with altimetry-derived water levels. The analysis of simulations indicates that interactions between the wetland and the river are bidirectional with most of the flow coming out from the river during the month of August and leaving out from the wetlands during the month of September. The wetlands respond in three different ways, i.e., (i) gaining stage, (ii) wetland and river in equilibrium and (iii) loosing stage, which is reflected on water levels of the river and wetland. This study demonstrates complex interaction processes happening between the Kosi river and its surrounding wetlands.

Keywords. Flood-plain wetland; river modelling; satellite altimetry; HEC-RAS model; unsteady flow analysis.

\section{Introduction}

Surface water balance is an important parameter in global hydrologic cycle. The major component of it comprises mainly lakes, wetland water storages and river discharges, yet they are gauged poorly (e.g., Stokstad 1999; Shiklomanov et al. 2002). The reliable surface water budget largely depends on 
measurements of river and reservoir/lakes/wetlands and their interactions for better understanding of global hydrologic cycle. However, still large-scale dynamics of surface water storage and their interactions with river discharge is unknown (Alsdorf 2003). Hence, better understanding of river and flood-plain wetland interactions are important for better estimation of water budgeting. Flood-plain wetlands are seasonal water bodies formed along the main course of the river. The wetlands receive river flow during the monsoon months. The monsoonal rainfall inundates the vast area of flood plains in the Kosi river basin, India (Sinha 2008). During the initiation of monsoon season, these wetlands remain small and isolated. With progression of the monsoon, the upland catchment runoff increases the river flow and floods the nearby wetlands. Hence, flood-plain wetlands initiate the flow interaction process with the river. The flow interaction of the river with flood-plain wetlands increases in its area, which spread from few metres to several kilometres along the river. This interaction depends on the hydrologic regime of the river and wetlands. As the water level reaches the riverbank level, excess water overflows to the nearby wetlands. During the non-monsoon season, water level in the river recedes to the bank level and then the interaction between wetlands and river tends to cease. Hence, the wetland becomes an isolated water body; its extent also decreases and eventually it dries up. The river also interacts with the surrounding wetlands through subsurface, but this interaction depends on the nature of subsurface soil and geology existing between the river and the wetland. The extent of inundation area, connectivity of wetlands to the main river and depth of the flood-plain wetlands vary seasonally and annually according to inflow, precipitation and evaporation rates (Birkett 1998). Wetland connectivity has many implications on aquatic biota, nutrient recycling and wetland ecology (Junk et al. 1989). To study the impacts of changing climate on wetland hydrology and their biodiversity, one often needs a long-term hydrological data of wetlands. Wetlands are rarely gauged due to spatiotemporal variations in the inundation extent and extremely complex flow interaction with the river (Frappart et al. 2005; Wen et al. 2013). The wetlands are either not represented in the hydrodynamic models to study the interaction processes or represented so coarsely that they provide hydrologic information of limited value (Wen et al. 2013). The lack of in-situ hydrological data for wetlands creates a challenging task for many of the researchers to understand river and wetland flow interactions. Karim et al. $(2012,2014)$ used the modelling technique to study the timing and duration of connectivity of the wetlands to the main river for flood events of different return periods. Satellite altimetry provides a unique opportunity to study the river and wetland interactions for a region with limited gauging data set. It has become a major source of hydrological data for many of the un-gauged catchments (Birkett 1995). Advancement in the field of satellite altimetry has improved the accuracy of water level retrieval over many of the un-gauged catchments (Koblinsky et al. 1993). However, the limitation with satellite altimetry data is the coarse temporal resolution, which may vary from 10 to 35 days based on the satellite track (Roux et al. 2008). Irrespective of these limitations, there are many applications of satellite altimetry in the field of inland water body monitoring, river flow depth and river flow estimation (Chander et al. 2014; Dubey et al. 2014, 2015a, b; Verron et al. 2018). The utilisation of satellite altimetry and optical satellite images has made it possible to estimate the water storage variations over lakes (Crétaux et al. 2011) and over inundated areas of the Negro river basin, the lower Mekong basin and the lower $\mathrm{Ob}$ river basins (Frappart et al. 2005, 2006, 2010). Duan and Bastiaanssen (2013) have estimated water volume variations of lake Mead (USA), Lake Tana (Ethiopia) and Lake Ijssel (The Netherlands) using various altimetry data and satellite images without making use of $i n$ situ data. To evaluate the performance of satellite altimetry and hydrodynamic model-derived water levels, Siddique-E-Akbor et al. (2011) performed an inter-comparison study for Ganga-BrahmaputraMeghna river basins. Papa et al. (2006), Getirana et al. (2009), Dubey et al. (2014, 2015a,b) and Gupta et al. (2015) have evaluated the satellite altimetry-derived river stage variations and used this information to develop rating curves at different reaches of the river. Leon et al. (2006) have proposed a method by combining satellite altimetry water level and flow routing model to establish rating curves for remote locations in the Amazon basin. In this study, we have performed the model simulations over the lower reach of the Kosi river with surrounding major flood-plain wetlands to understand the exchange of flow interactions using water level derived from satellite altimetry. Water level products derived from TOPEX/POSIEDON $(\mathrm{T} / \mathrm{P}) 18 \mathrm{~Hz}$ waveform data are used to perform 
model simulations. The $\mathrm{T} / \mathrm{P}$ satellite track 155 intersects the downstream of Kosi river and the nearby wetland. HEC-RAS model is set up over the Kosi river along with major wetlands using in-situ, altimetry and optical satellite data. The model is extensively calibrated for the period of 1993-1996 using different values of Manning's roughness coefficient for the river bed and bank. The calibrated model is simulated for the period of 1993-2000 to estimate flow interaction between the river and the wetlands. This study demonstrates the utility of satellite altimetry-derived river and wetland water level variation to understand the dynamic interactions between the Kosi river and its surrounding flood-plain wetlands.

\section{Study area and data}

\subsection{Kosi river}

Kosi is one of the major tributaries of the Ganga river originating from the Nepalese Himalayas and enter India near to Bhimnagar. It has three major tributaries Sun Kosi, Arun Kosi and Tamar Kosi (Sinha et al. 2014). The average annual rainfall within the basin varies from 1000 to $1600 \mathrm{~mm}$. The average annual discharge varies from 500 to $6000 \mathrm{~m}^{3} / \mathrm{s}$ with flood peak discharge reaches up to $7000 \mathrm{~m}^{3} / \mathrm{s}$ (Chakraborty et al. 2010). The study area covers the downstream part of the Kosi river, which starts from Baltara $\left(25^{\circ} 30^{\prime} 8.41^{\prime \prime} \mathrm{N} ; 86^{\circ} 44^{\prime} 11.84^{\prime \prime} \mathrm{E}\right)$ and reaches up to Kursela $\left(25^{\circ} 25^{\prime} 3.48^{\prime \prime} \mathrm{N} ; 87^{\circ} 13^{\prime} 34.14^{\prime \prime} \mathrm{E}\right)$, which makes the total length of about $51 \mathrm{~km}$ and finally meets the Ganga river. The Kosi river flood plain consists of many wetlands that interact with the river at different seasons and at different hydrologic regimes of the river. The $\mathrm{T} / \mathrm{P}$ satellite (track-155) passes over the downstream of the Kosi and its nearby wetland.

\subsection{Altimetry data}

Over inland water bodies, satellite altimetry can be used to detect variations in water levels for the lakes, reservoirs and rivers. The applications of altimetry-derived water level over rivers and wetlands have increased the scope to measure the hydrological variability of the ungauged and sparsely gauged basins. It provides unique source of information over the flood plains, whereas the in-situ data records are generally available over the narrow reaches of the river (Frappart et al.
2005). Hydroweb database provides water levels of large rivers, lakes and wetlands around the world. In India, it provides data for the Ganges, the Brahmaputra, the Godavari and the Krishna rivers. The water level time series can be obtained from LEGOS website (www.legos. obsmip.fr/soa/hydrologie/hydroweb) for the major rivers of India. The present study utilises the water level time series derived from $\mathrm{T} / \mathrm{P}$ altimeter mission. The $\mathrm{T} / \mathrm{P}$ radar altimeter launched on 10 August 1992 has dual frequency altimeters (13.6 GHz, Ku band and $5.3 \mathrm{GHz}, \mathrm{C}$ band) with 10 -day repeat cycle and $350-\mathrm{km}$ equatorial intertrack spacing. The orbit of $\mathrm{T} / \mathrm{P}$ satellite is at an altitude of $1334 \mathrm{~km}$ with global coverage extending to $66^{\circ}$ latitudes (Birkett 1995). Zhang et al. (2006) have compared the $\mathrm{T} / \mathrm{P}$ radar altimeter water level with ground measurements over a lake. They found out that the root mean squares differences amount to $0.08 \mathrm{~m}$ (about $2.21 \%$ of the range of values in the time series). Altimetry missions such as Geosat and ERS 1 have served before $\mathrm{T} / \mathrm{P}$ and preceded by GFO, ERS-2, Envisat and Jason-1 in the past and SARAL/Altika, HY-2, Cryosat, Jason-2 and SPOT are the current missions (www.aviso.altimetry.fr/ en/missions.html). In this study, water level time series is obtained for the two virtual stations of $\mathrm{T} / \mathrm{P}$ satellite track: $155-3$ on the river and $\mathrm{T} / \mathrm{P}$ virtual station 155-2 on wetland (figure 1). The water level time series derived from $\mathrm{T} / \mathrm{P}$ altimeter data is used to calibrate and simulate the HEC-RAS model over the Kosi river to study the river and flood-plain wetland interactions at the different hydrological regimes.

\subsection{Optical satellite data}

Spatial and temporal variations of flood-plain wetlands are mapped from multi-temporal Landsat satellite images. The relationship between wetland inundation and river flow is understood using satellite images (Frazier et al. 2003). The Landsat satellite at an altitude of $705 \mathrm{~km}$ provides the images of Earth surface with the repeat cycle of 16 days. Landsat (TM) consists of seven spectral bands including thermal (TIR) ranging from visible region to middle infrared region, i.e., $0.45-2.35 \mu \mathrm{m}$ with $30 \mathrm{~m}$ spatial resolution. Landsat (ETM) consists of similar spectral bands with an additional panchromatic band with $15 \mathrm{~m}$ spatial resolution and also TIR band with $60 \mathrm{~m}$ spatial resolution (landsat.usgs.gov/about_landsatmissions.php). Landsat 5 (TM) and Landsat 7 (ETM) 

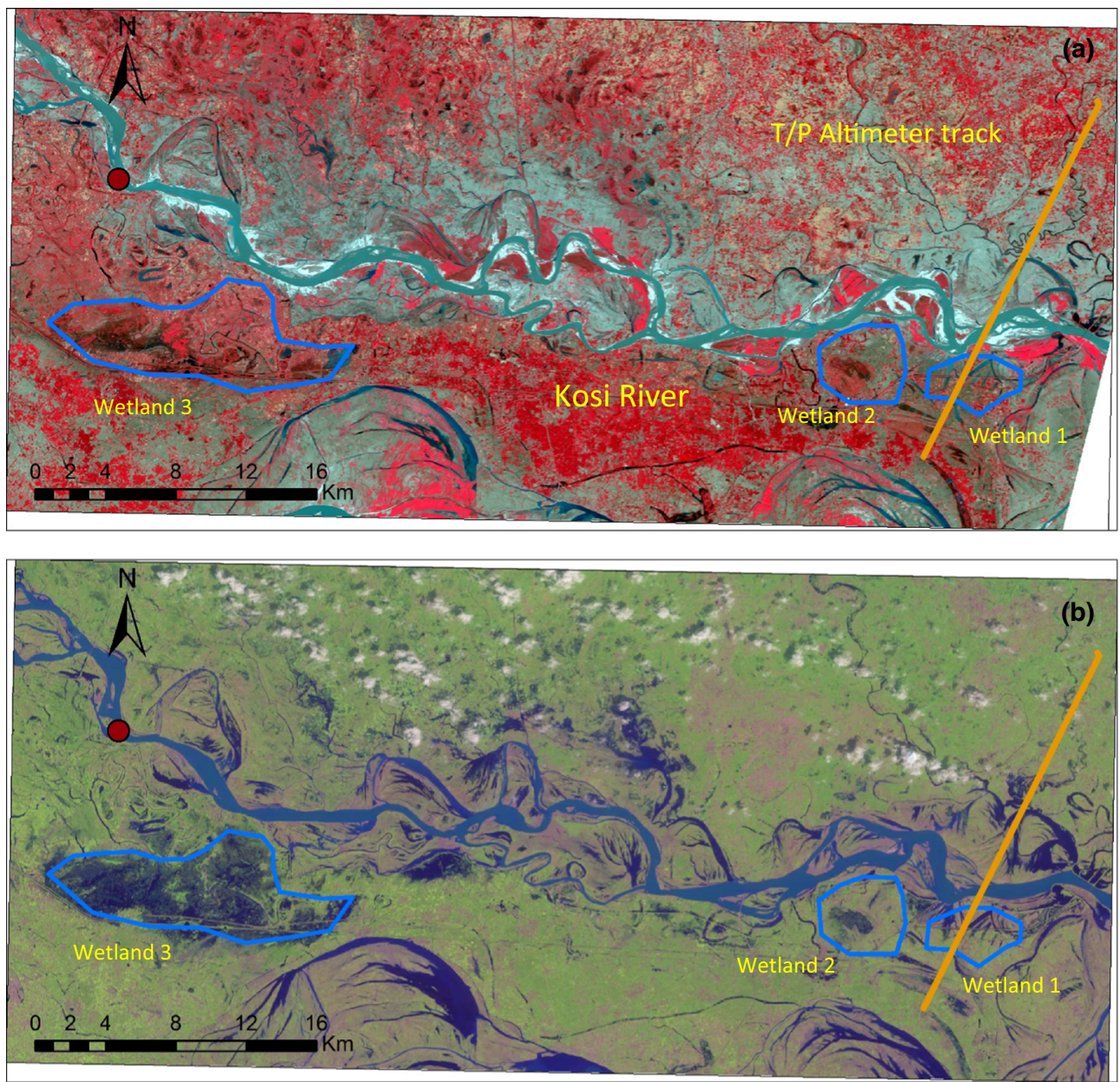

Figure 1. Satellite images: (a) monsoon and (b) non-monsoon showing the study area, location of gauging station, wetlands and altimetry track (track-155) over the Kosi river and the wetland 1.

satellite images are used to identify the temporary and permanent wetlands within the study area, which are connected to lower reach of the Kosi river. In this study, we have used false colour composite to map the wetlands, which consist of NIR $(0.77-0.90 \mu \mathrm{m}), \operatorname{RED}(0.63-0.69 \mu \mathrm{m})$ and GREEN $(0.52-0.60 \mu \mathrm{m})$ at $30-\mathrm{m}$ spatial resolution in spectral bands for TM and ETM satellite data. The wetlands are mapped at 1:25,000 scale.

\subsection{River cross-section and gauge data}

Central Water Commission (CWC) of India provides field measurements such as river cross-sections and river flow variations. The cross-sections were measured from left bank to right bank using echo sounder equipment. The total numbers of crosssections available for the Kosi river are 10 with an average survey chainage of $5 \mathrm{~km}$. The typical cross-section of the Kosi river is represented in figure 2. The daily discharge data is obtained from gauge station at Baltara, Khagaria district, Bihar, on the Kosi river maintained by Central Water Commission (CWC), India. Table 1 represents the summary of data set used in this study and figure 3 shows the field photographs collected during the field visit in the month of December 2014.

\section{Methodology}

\subsection{Hydrodynamic modelling}

HEC-RASv-4.1, a one-dimensional hydrodynamic model, is often used to simulate steady and unsteady flow simulations for the rivers. It could also be used to perform sediment transport computations and water quality analysis. In this study, an unsteady flow analysis was carried out without including the sediment transport and water quality modules. In the model, unsteady flow equations were expressed in terms of the set of partial differential equations to solve the water gravity flow in open channel 


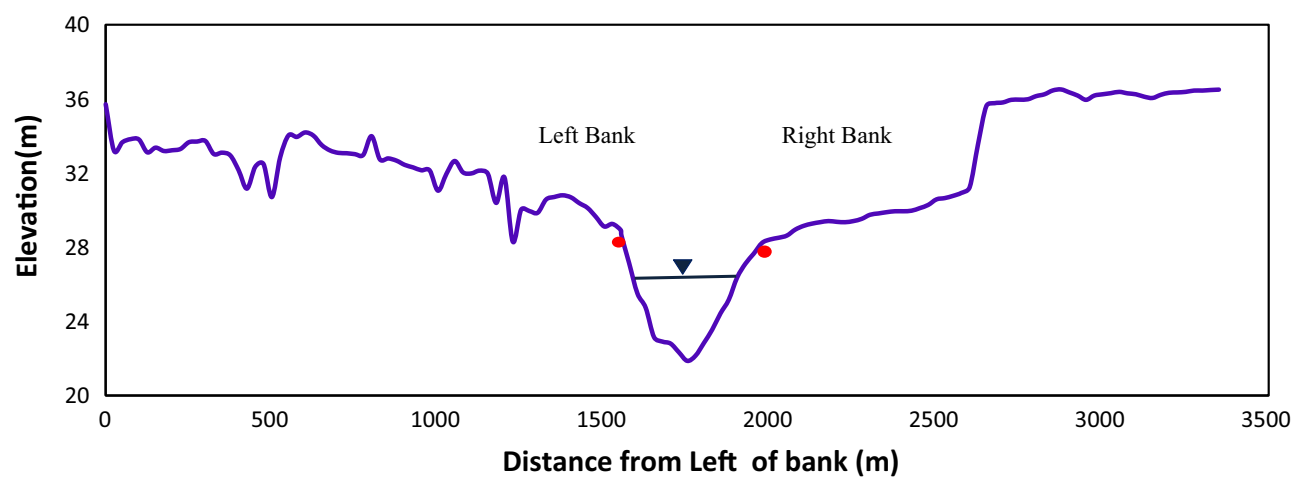

Figure 2. Typical cross-section from left to the right of bank of the Kosi river at downstream location.

Table 1. Data used in this study.

\begin{tabular}{lcc}
\hline Data type & Description & Data source \\
\hline River cross-sections & Cross-section data along the river reach was used to & Central Water Commission (CWC) \\
& set up the HEC-RAS model & Board, India \\
Gauge data & Water level and discharge data were used as a model & Central Water Commission (CWC) \\
& input to the HEC-RAS to simulate unsteady flow & Board, India \\
Optical satellite data & Identification of key wetlands and their extent was & http://earthexplorer.usgs.gov/ \\
& done using optical satellite images & http://www.legos.obs-mip.fr/soa/ \\
Satellite altimetry data & T/P track 155-3 data as a boundary condition to the & hydrologie/hydroweb/ \\
(TOPEX/POSIEDON) & HEC-RAS and track 155-2 data to generate water & \\
\hline
\end{tabular}

(Chow et al. 1988). In the model, the off channel ponding, i.e., wetlands are modelled as storage areas that exchange water with channel and flow in the overbank was approximated as a flow through the separate channel. Hence, the governing equations for the channel and flood plain were written individually using the basic Saint-Venant equations by including storage term in the flood plain. These equations were approximated using implicit finite difference scheme.

The continuity equation describing conservation of mass and the momentum equation are

$$
\begin{aligned}
& \frac{\partial A}{\partial t}+\frac{\partial S}{\partial t}+\frac{\partial Q}{\partial x} \pm q_{1}=0 \\
& \frac{\partial Q}{\partial t}+\frac{\partial Q V}{\partial x}+g A\left(\frac{\partial Z}{\partial x}+S_{\mathrm{f}}\right)=0
\end{aligned}
$$

where $x$ is the distance along the channel, $t$ is the time, $Q$ is the flow, $A$ is the cross-sectional area, $S$ is the storage from non-conveying portions of cross-section and $q_{1}$ is the lateral inflow per unit distance.

The above equations are written for channel and flood plain individually and approximated using implicit finite difference scheme (Barkau 1987).
The combined equations for unsteady flow analysis are represented as

$$
\begin{aligned}
& \Delta Q+\frac{\Delta A_{\mathrm{c}}}{\Delta t} \Delta x_{\mathrm{c}}+\frac{\Delta A_{\mathrm{f}}}{\Delta t} \Delta x_{\mathrm{f}}+\frac{\Delta S}{\Delta t} \Delta x_{\mathrm{f}}-\bar{Q}_{1}=0 \\
& \frac{\Delta\left(Q_{\mathrm{c}} \Delta x_{\mathrm{c}}+Q_{\mathrm{f}} \Delta x_{\mathrm{f}}\right)}{\Delta t \Delta x_{\mathrm{e}}}+\frac{\Delta\left(Q_{\mathrm{c}} V_{\mathrm{c}}+Q_{\mathrm{f}} V_{\mathrm{f}}\right)}{\Delta x_{\mathrm{e}}} \\
& +g \bar{A}\left(\frac{\Delta Z}{\Delta x_{\mathrm{e}}}+\overline{S_{\mathrm{f}}}\right)=0,
\end{aligned}
$$

where $\mathrm{c}$ and $\mathrm{f}$ represent channel and flood plain, respectively.

\subsection{Modelling river-wetland flow interactions}

Landsat 5 (TM) and Landsat 7 (ETM) satellite images were used to identify the extent of the wetlands for different years. Three major wetlands associated with the Kosi river were identified from satellite images. The wetland extents were extracted for different seasons of different years. The $\mathrm{T} / \mathrm{P}$ satellite (track-155) was only passing over the wetland 1 ; therefore, water levels in other wetlands were estimated using the slope correction approach. The slope corrections were applied to 

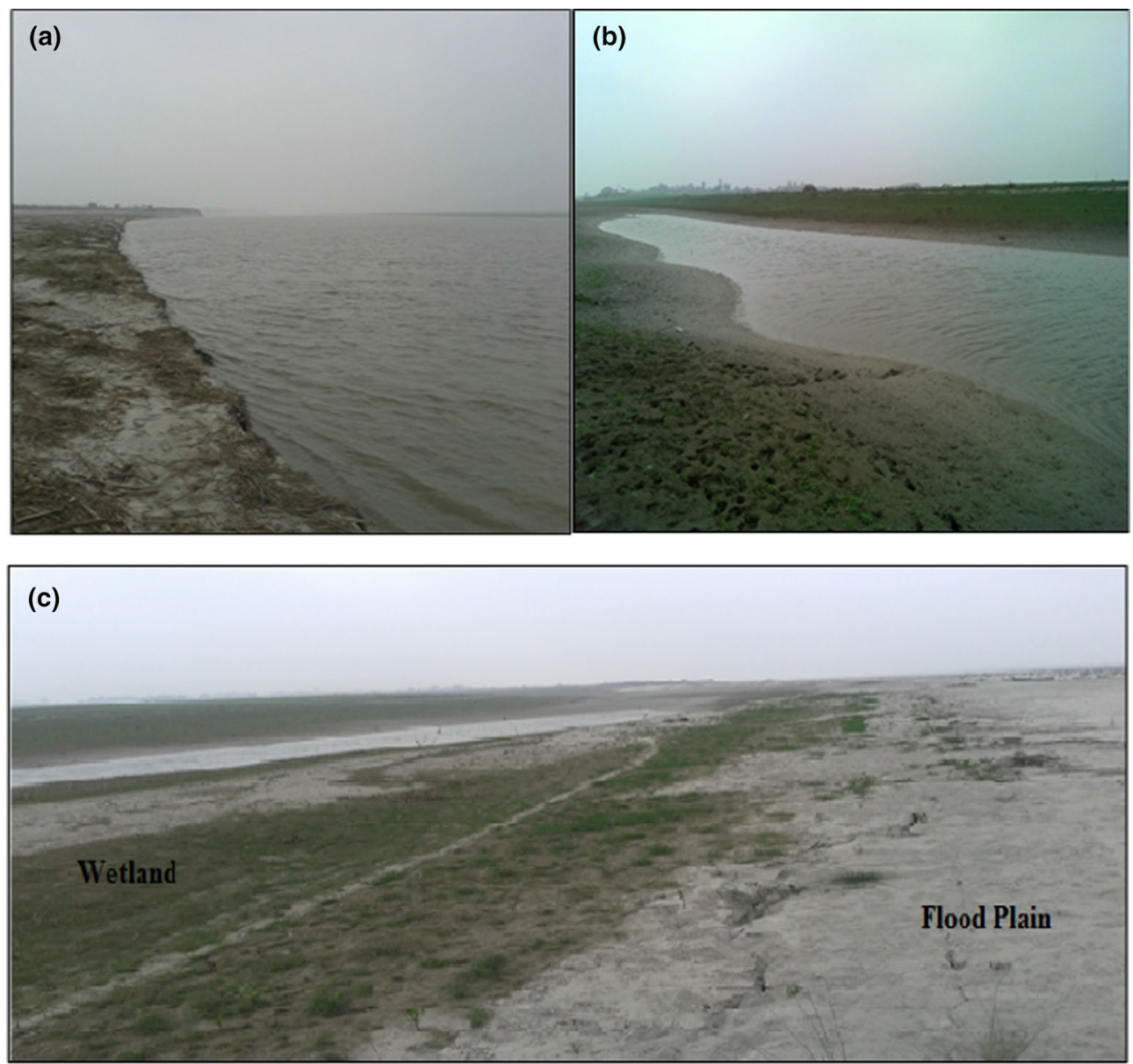

Figure 3. Field photographs of study area during the month of December 2014: (a) Kosi river; completely within the main channel, (b) isolated wetland close to the river having width more than $5 \mathrm{~m}$ and average depth measured using echo sounder was $0.85 \mathrm{~m}$ and (c) another wetland found in the receding phase and flood plain is also seen in the photograph.

the wetlands 2 and 3 based on the water level values of wetland 1 . Hence, we used the longitudinal slope derived using SRTM digital elevation model. The $\mathrm{T} / \mathrm{P}$ altimeter-derived water levels were with reference to geoid and HEC-RASsimulated water levels were referenced to mean sea level. Hence, datum correction was applied prior to any comparison between the two data sets. The methodology used for datum correction was followed similar to the method adopted by Papa et al. (2010), Siddique-E-Akbor et al. (2011) and Dubey et al. (2014). The difference of mean in two data sets was taken as an offset for the datum correction. The mean difference of water levels was estimated from the period of 1993-2000. The water depth in the wetland 1 was found to be about $1 \mathrm{~m}$ based on field survey during the non-monsoon season (see Appendix). The volume of water stored in the wetlands 1, 2 and 3 was estimated by multiplying the mean monthly values of water depths with the respective monthly area of the wetlands obtained using optical satellite images. The amount of water stored in the wetlands with respect to different water levels was given as an input to the HEC-RAS model. The model was setup with the available cross-sections for the lower reach of the Kosi river of about $51 \mathrm{~km}$ (figure 4). The chainage interval between cross-sections varies from 4 to $10 \mathrm{~km}$. In the HEC-RAS setup of Kosi river with its associated flood-plain wetlands, wetlands were represented as storage areas that exchange water with the channel (figure 4). These storage areas are usually linked to the channel by using a hydraulic connection like lateral structure. In the present study, wetland 1 is linked to the cross-sections 2 and 3 ; wetland 2 is linked to cross-sections 3 and 4 ; wetland 3 is linked to cross-sections 8 and 9 . The daily discharge variations (observed at Baltara gauge station) in the river were used as an upstream boundary condition and the altimetry-derived water level in the downstream was provided as a downstream 
Baltara G \& D site

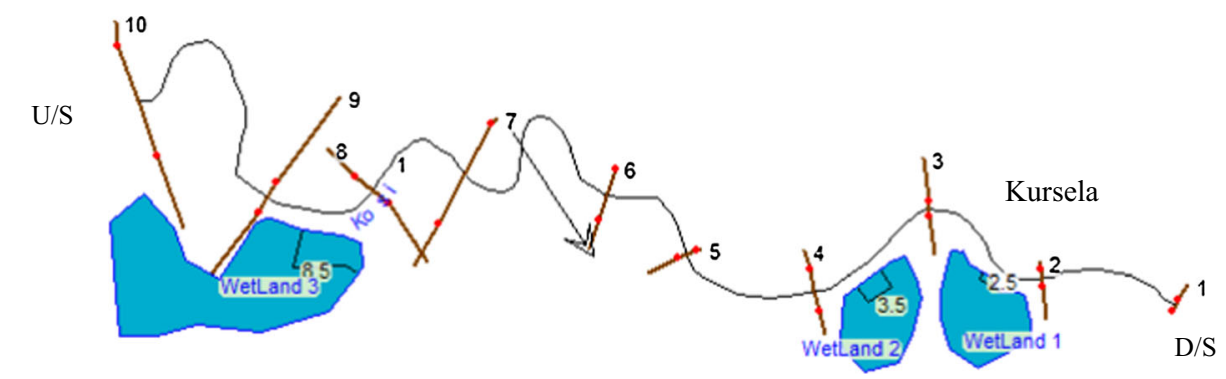

Note: Brown lines indicate cross sections and red dots indicate bank stations

Figure 4. HEC-RAS model setup for lower reach of the Kosi river and its associate flood-plain wetlands.

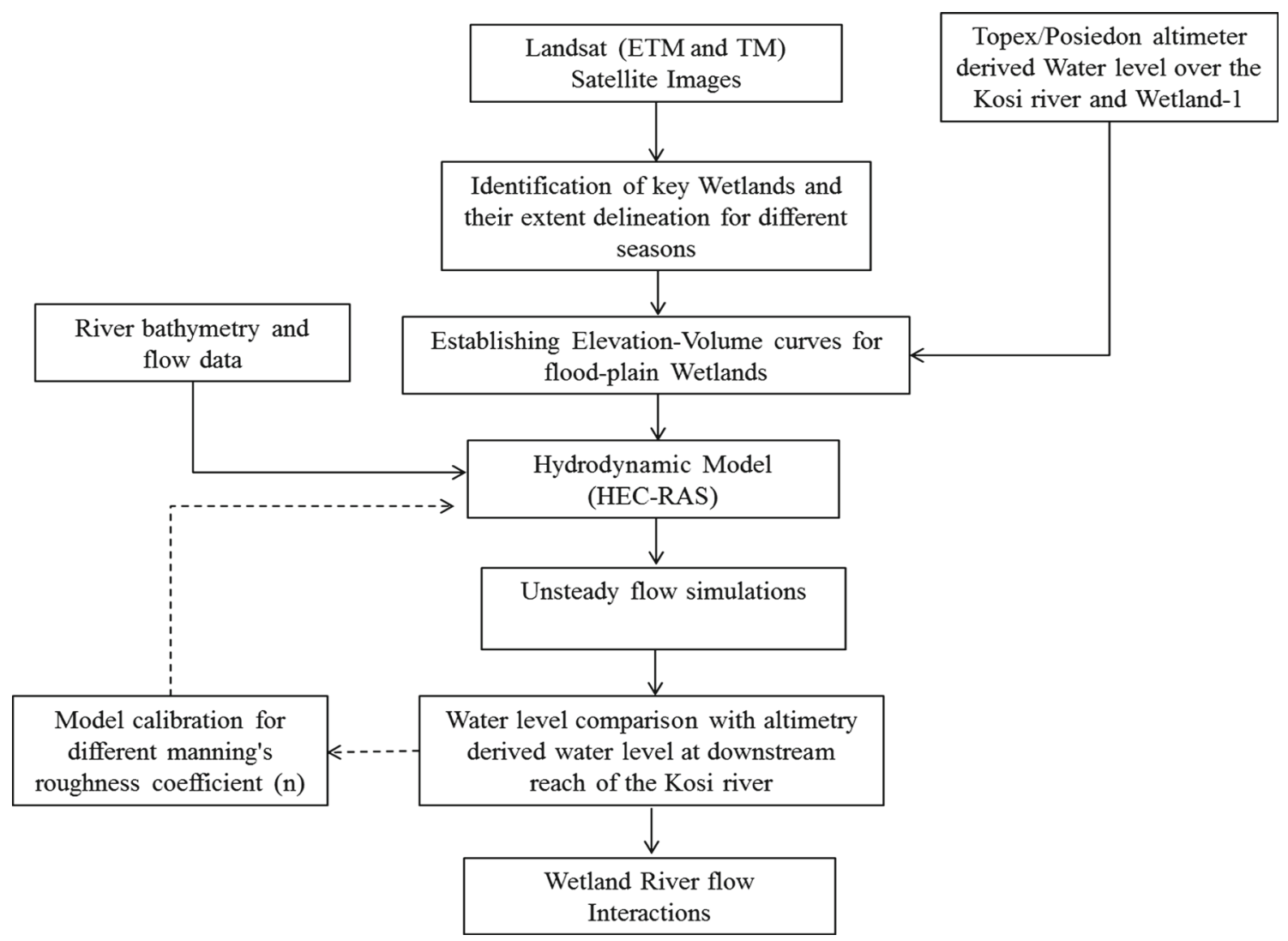

Figure 5. Flow chart illustrating the methodology adopted for modelling flow interactions between river and flood-plain wetland.

boundary condition to perform the unsteady flow simulations. The longitudinal slope of the river reach was also included in the model. The longitudinal slope of lower reach of the Kosi river was taken as $0.00017 \mathrm{~m} / \mathrm{m}$ (Chakraborty et al. 2010). Initial conditions to the wetlands were assumed to be dry and the river flow was considered to be the beginning value of discharge hydrograph.
The unsteady flow simulations were performed for the monsoon season to estimate the river and flood-plain wetland interactions for different years. The flow chart (figure 5) systematically describes the methodology followed in the present study to understand the wetland-river flow interactions by utilising the optical satellite images and altimetryderived water levels. 


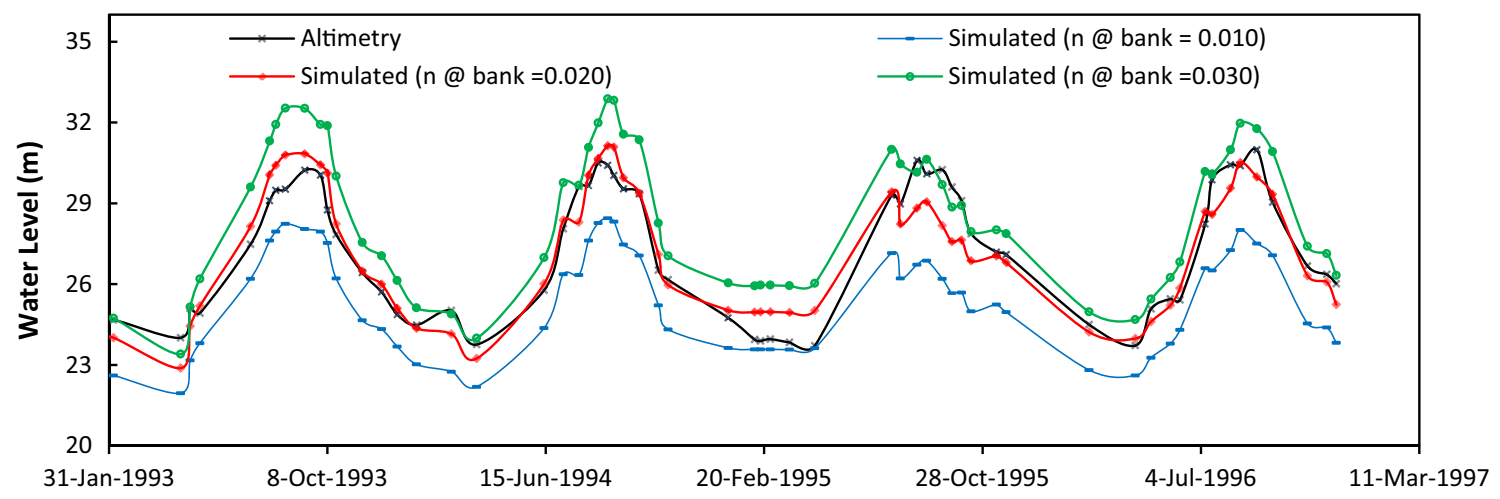

Figure 6. Performance analysis of HEC-RAS simulated water level with altimetry-derived river stage variations for different values of Manning's roughness coefficient $(n)$.

Table 2. Statistical performance of HEC-RAS model simulations for different Manning's roughness coefficients $(n)$.

\begin{tabular}{llcccc}
\hline & \multicolumn{2}{l}{ Manning's roughness coefficient $(n)$} & & \\
Sl. & $\begin{array}{c}\text { Flood } \\
\text { plain }\end{array}$ & Channel & $\begin{array}{c}\text { Absolute mean } \\
\text { error }(m)\end{array}$ & $\begin{array}{r}\text { RMSE } \\
(m)\end{array}$ & $\begin{array}{l}\text { Nash-Sutcliffe } \\
\text { efficiency (NS) }\end{array}$ \\
\hline 1 & 0.010 & 0.008 & 1.929 & 2.120 & 0.2096 \\
2 & 0.020 & 0.018 & 0.682 & 0.837 & 0.85 \\
3 & 0.030 & 0.028 & 1.263 & 1.5088 & 0.5999 \\
\hline
\end{tabular}

Note: Error is estimated as absolute difference of TOPEX/POSIEDON and HEC-RAS water levels.

\section{Model calibration and validation}

The model calibration was done using Manning's roughness coefficient. HEC-RAS-simulated river stages for different values of Manning's roughness coefficient were compared with $\mathrm{T} / \mathrm{P}$ 155-3 river stages. $\mathrm{T} / \mathrm{P}$ 155-3-derived river stages were available for the period of 1993-2000, of which 50\% of the data (1993-1996) was used for model calibration and rest $50 \%$ was used to validate the model. The comparative analysis was carried out for different values of Manning's roughness coefficient (figure 6) for the Kosi river. It was found out that the general trend for different Manning's roughness coefficient $(n)$ was well picked up by the model. The variation in Manning's roughness coefficient improved the results significantly with the close agreement to the altimetry-derived water level. The statistical parameters such as root mean square error (RMSE), Nash-Sutcliffe efficiency coefficient (NS) and absolute mean errors were used between the simulated and altimetry-derived water levels to determine the optimum values of Manning's roughness coefficient (table 2). The calibrated values of Manning's roughness coefficient were found to be 0.020 for the river bank and
0.018 for the main channel of the river. It was to be noted that bank stations in the model were fixed according to the field observations noticed during the lean season. The model validation was carried out for the period of 1997-2000 (figure 7).

\section{Results and discussion}

The hydrodynamic model setup was done for the available cross-sections along the Kosi river and its associated flood-plain wetlands. Unsteady flow simulations were carried out by using initial and boundary conditions as discussed in section 3.2.

A statistical analysis was carried out between the altimetry-derived water levels and the simulated model water levels on the river for the study period to evaluate the performance of the model (figure 8). It was found out that simulated and altimetry-derived river stages were in close agreement with $0.84 \mathrm{~m} \mathrm{RMSE}$ and $0.85 \mathrm{NS}$ for Manning's roughness coefficient $(n)$ of 0.020 for river bank and 0.018 for the main channel. However, the simulated values were slightly overpredicted for few years during the monsoon season. 


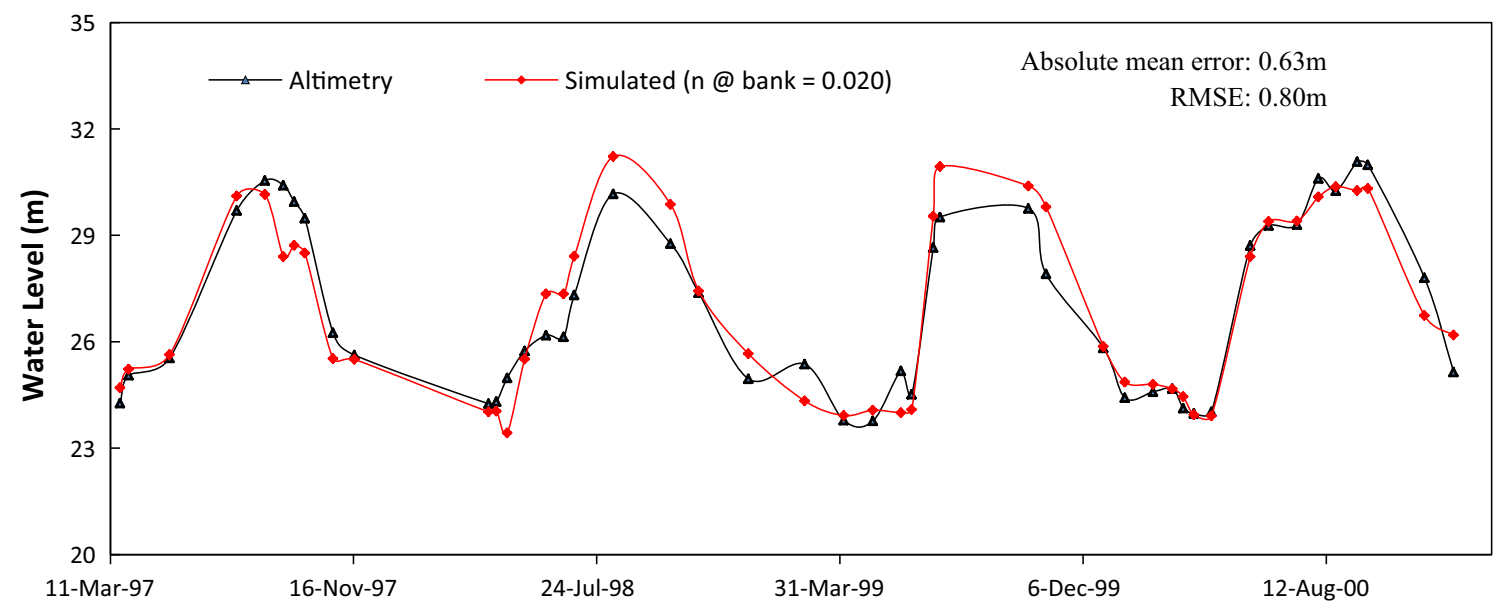

Figure 7. HEC-RAS model validation for the period of 1997-2000.

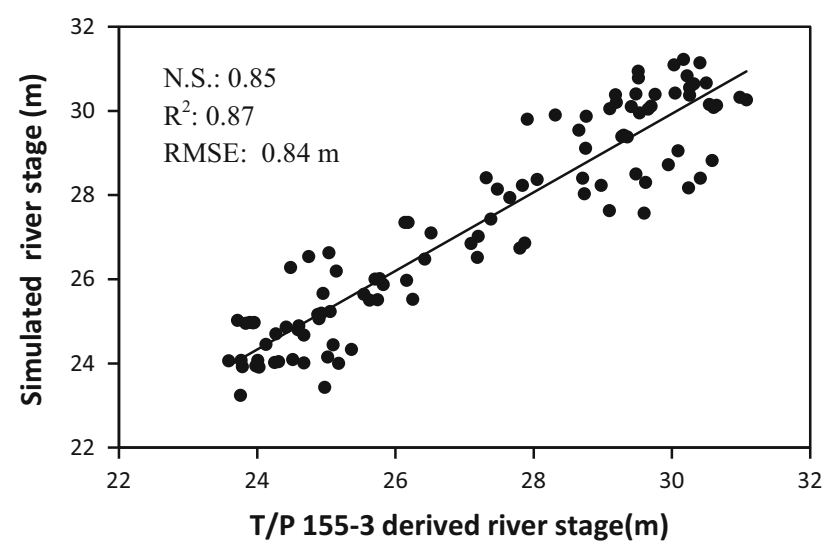

Figure 8. Comparison of simulated water level and altimetry-derived water level (T/P 155-3) for the Kosi river.

In the case of the wetland, the model-simulated water depths were found to be in close range of water depth observed during the field survey. The comparative analysis was done between both the altimetry-derived and model-simulated water levels of wetland 1 vs. water level of the river (figure 9). It clearly indicates the behaviour of the wetland of varying river stages in three ways: (i) wetland at a gaining stage (1) on the curve, (ii) the linear rise in the water level after a threshold value of $30 \mathrm{~m}$. After crossing the threshold point (2) on the curve wetland and the river in equilibrium and (iii) wetland is in a losing stage (3) on the curve. The results also showed that downstream wetlands (1 and 2) start to gain water when the river water level crosses $27.6 \mathrm{~m}$ and rises its stage till the river level reaches $30.5 \mathrm{~m}$. Furthermore, the increase in river water level (up to $31.5 \mathrm{~m}$ ) makes the river and downstream wetlands to act as a single body, i.e., river and wetlands are at equilibrium stage. As the river water level recedes, it is observed that the wetlands are contributing to river till its stage reaches

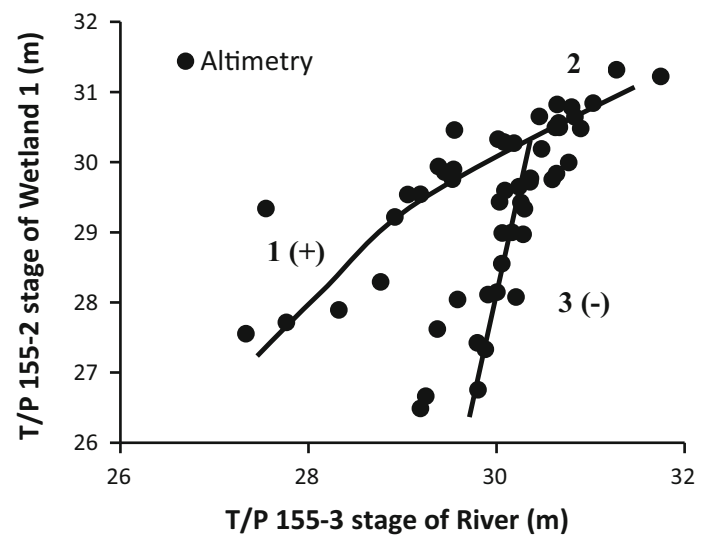

$1(+)$ : Rising levels;

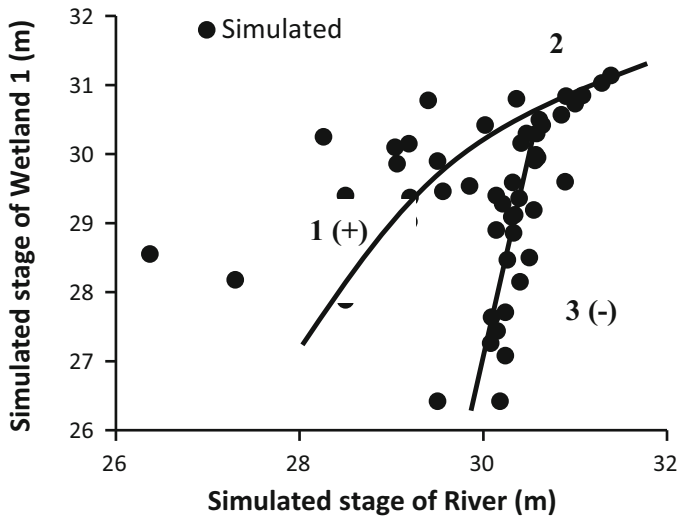

2: Equilibrium levels;

3 (-): Falling levels

Figure 9. Comparative analysis of water level between wetland (wetland 1 ) and the Kosi river from $\mathrm{T} / \mathrm{P}$ altimeter-derived water levels and the HEC-RAS-simulated water levels. 


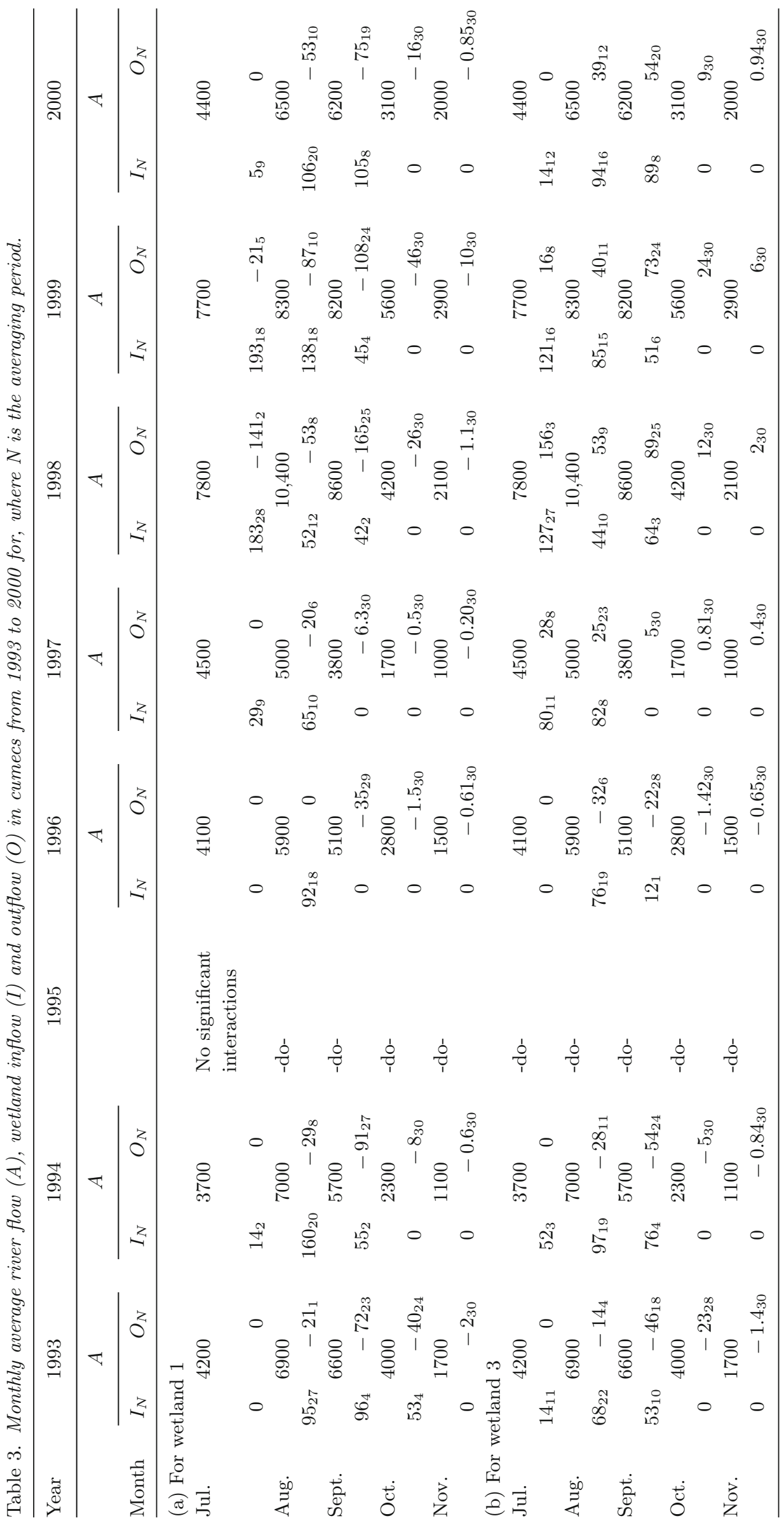



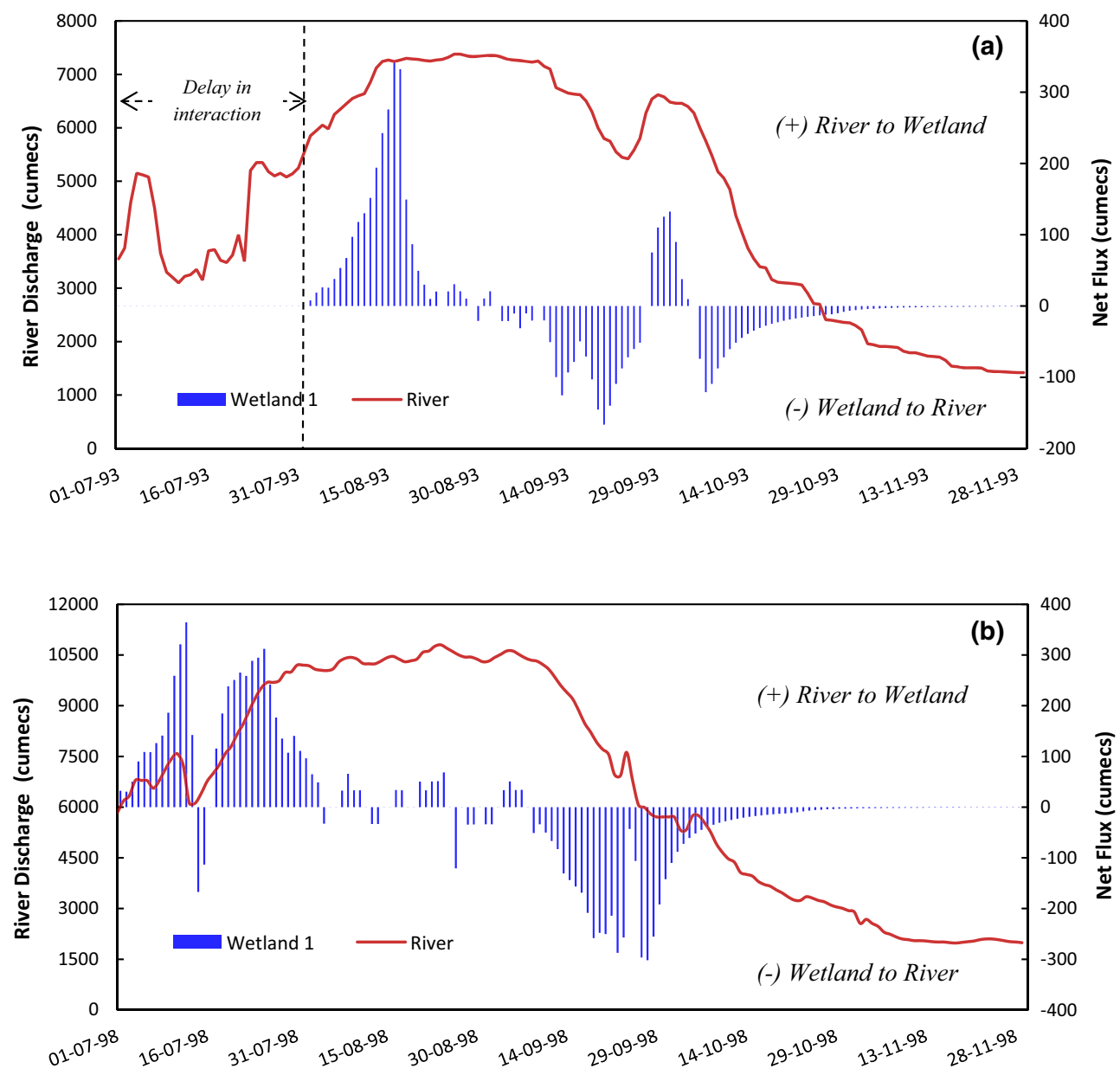

Figure 10. River wetland (wetland 1) flow interactions for the years 1993 and 1994.

Table 4. Cumulative inflow and outflow of downstream (D/S) wetlands (wetlands 1 and 2) and corresponding storage.

\begin{tabular}{lccc}
\hline Year & $\begin{array}{c}\text { Cumulative seasonal } \\
\text { inflow to, D/S } \\
\text { wetland }\left(\mathrm{Mm}^{3}\right)\end{array}$ & $\begin{array}{c}\text { Cumulative seasonal } \\
\text { outflow from D/S } \\
\text { wetland }\left(\mathrm{Mm}^{3}\right)\end{array}$ & $\begin{array}{c}\text { Seasonal } \\
\text { storage in D/S } \\
\text { wetland }\left(\mathrm{Mm}^{3}\right)\end{array}$ \\
\hline 1993 & 282.1306 & -240.391 & 41.73984 \\
1994 & 284.8349 & -244.002 & 40.83264 \\
1995 & & No significant interactions & \\
1996 & 133.2979 & -90.6448 & 42.65309 \\
1997 & 76.17024 & -33.8429 & 42.32736 \\
1998 & 515.8598 & -484.946 & 30.91392 \\
1999 & 530.8762 & -499.444 & 31.43232 \\
2000 & 254.0246 & -213.046 & 40.97866 \\
\hline
\end{tabular}

to $29 \mathrm{~m}$ and disconnects with river and remains as an isolated body. Similarly, upstream wetland (wetland 3) gains flow at a river stage of $31 \mathrm{~m}$ and remains equilibrium at river stage of $33.75 \mathrm{~m}$, and a decrease in river level at this stage makes the wetland to lose it flow to the river and remains isolated with its stage at $32.5 \mathrm{~m}$.

\subsection{River and wetland flow interaction}

The river-wetland flow interactions were carried out between the Kosi river and its associated flood-plain wetlands for the period of 1993-2000 using altimetry-derived river stage records and hydrodynamic model simulations. The monthly 
Table 5. Cumulative inflow and outflow of upstream (U/S) wetland (wetland 3) and corresponding storage.

\begin{tabular}{lccc}
\hline Year & $\begin{array}{c}\text { Cumulative seasonal } \\
\text { inflow to U/S } \\
\text { wetland }\left(\mathrm{Mm}^{3}\right)\end{array}$ & $\begin{array}{c}\text { Cumulative seasonal } \\
\text { outflow from U/S } \\
\text { wetland }\left(\mathrm{Mm}^{3}\right)\end{array}$ & $\begin{array}{c}\text { Seasonal } \\
\text { storage in U/S } \\
\text { wetland }\left(\mathrm{Mm}^{3}\right)\end{array}$ \\
\hline 1993 & 188.1343 & -139.298 & 48.83587 \\
1994 & 197.3652 & -153.285 & 44.08042 \\
1995 & & No significant interactions & \\
1996 & 125.3223 & -79.1899 & 46.13242 \\
1997 & 131.8464 & -86.959 & 44.88739 \\
1998 & 374.3263 & -334.193 & 40.13366 \\
1999 & 337.4292 & -312.556 & 24.87283 \\
2000 & 209.0249 & & 48.02458 \\
\hline
\end{tabular}

averaged river-wetland interactions were analysed for different years (table 3 ). The positive values in table 3 represent water leaving from river to flood-plain wetlands, whereas negative values indicate wetland contribution to the river flow. It was found out that threshold value of river discharge of $5000 \mathrm{~m}^{3} / \mathrm{s}$ is required to initiate the river and flood-plain wetlands interactions (figure 10). The results highlighted the interactions between the river and flood-plain wetlands and were bi-directional with the significant inflow to the wetlands observed in the month of August. It was found out that during the receding phase of the river, floodplain-wetlands contribute to the river flow. The wetland contribution was found to be significant during the month of September (table 3), which gradually decreased during the month of October-November. The contribution of floodplain wetlands was initiated from the upstream wetland (wetland 3) and subsequently added by downstream located wetlands (wetlands 1 and 2). The reverse was observed when the river and floodplain wetlands lost the connectivity. It was found out that the flow interaction started when river flow exceeded the threshold value of $5000 \mathrm{~m}^{3} / \mathrm{s}$. Hence, the initiation and duration of flow interactions were different for different years. To highlight these processes, two different monsoon years were represented in figure 10. The flow interactions were started when river exceeded the threshold of $5000 \mathrm{~m}^{3} / \mathrm{s}$ in the year 1993 , whereas flow interactions started earlier for the flood year 1998. It established that water level dynamics govern the flow interaction process, duration and the amount of inflow/outflow between the river and the floodplain wetlands. Tables 4 and 5 summarise the wetlands cumulative inflow and outflow during the month of July-November for different years. It was observed that an annual averaged amount of monsoonal storage of $42.33 \mathrm{Mm}^{3}$ was accumulated in the upstream wetland (wetland 3) and $38.66 \mathrm{Mm}^{3}$ was stored in the downstream wetlands (wetlands 1 and 2). During the high flood seasons, the river flow interactions were very dynamic and resulted in an increase in the cumulative inflow and outflow of wetlands and thereby reduced net storage, relatively.

\section{Conclusion}

The river and flood-plain wetland dynamics are important in terms of water budgeting for a river basin. The wetlands also serve as a buffer and contribute to the river flow during the low flow (non-monsoon) period. In this study, satellite altimeter $(\mathrm{T} / \mathrm{P}$, track-155)-derived water levels over river and wetlands are used. The satellite altimetry-derived water levels are used for developing wetland extent and water elevation relation and also for hydrodynamic model calibration and validation. The calibrated model is used to simulate daily level surface flow interactions over the period of 1993-2000 between the Kosi river and its surrounding flood-plain wetlands. Statistical analysis is performed between altimetry-derived and model-simulated water levels. It was found out that simulated data result in good agreement $\left(R^{2}=0.87\right.$, RMSE of $\left.0.84 \mathrm{~m}, \mathrm{NS}: 0.85\right)$ with altimetry observations.

The following are the important findings in the present study:

(1) The flood-plain wetlands have responded in three different ways, i.e., (i) wetlands in a gaining stage, (ii) wetland and river in equilibrium 
and (iii) wetlands in a losing stage. The downstream wetlands start gaining flow at a river stage of $27.6 \mathrm{~m}$ and continue to rise and reach an equilibrium stage at a level of $31.5 \mathrm{~m}$. The upstream wetland gains at river stage of $31 \mathrm{~m}$ and remains equilibrium up to $33.75 \mathrm{~m}$.

(2) Wetlands responses depend on the river flow variations. The minimum threshold of 5000 $\mathrm{m}^{3} / \mathrm{s}$ (cumecs) is required to initiate riverflood-plain wetlands interactions.

(3) The flood-plain wetlands and river flow interactions are found to be bidirectional. The significant inflow to wetlands is observed in August with an average inflow of 101 cumecs in downstream wetlands and 78 cumecs in upstream wetland. The significant outflow to wetlands is in September with an average outflow of 80 cumecs in downstream wetlands and 49 cumecs in upstream wetland.

(4) An average seasonal storage of $42.33 \mathrm{Mm}^{3}$ in the upstream wetland and $38.66 \mathrm{Mm}^{3}$ in downstream wetlands are stored irrespective of monsoon flow variability.

The limitation of the present study is the revisit period of altimeters, large distance between two tracks over a river and uncertainty of retrieved water level over complex river morphology. Recent altimetry mission such as SARAL/Altika has improved the cross-track distance $(\sim 75 \mathrm{~km})$ between two tracks but it has poor revisit period (35 days). Use of multiple satellites can enhance the revisit period in satellite altimetry (e.g., Jason-2, Jason-3 and Sentinal-1A). Uncertainty on retrieved water level over complex water surfaces is still a challenge for accurate retrieval of water level, and thereby considering these limitations, altimetry provides great insight into the ungauged river basins for hydrological and hydrodynamic applications. With the technological development in satellite altimetry, future missions such as Surface Water Ocean Topography would provide the water surface topography. It would be more useful in two-dimensional study of river-wetland flow interactions.

\section{Acknowledgements}

The authors are grateful to the Central Water Commission (CWC) board of India for providing the bathymetry (river cross-section) and gauge data of the Kosi river. The authors also express their sincere gratitude towards the Space Applications Centre (SAC), Ahmedabad (ISRO), for funding the research through SARAL/Altika utilisation project.

\section{Appendix: Field campaign (Kosi river)}

The field campaign was done to understand in detail about the river-wetlands behaviour - a field cum interaction survey was conducted in the month of December 2014. The downstream wetlands in the study area were chosen to conduct the field survey. The river was completely within the

Table A1. Details of information collected as a part of field survey.

Wetland location: Nagrah village latitude: $25^{\circ} 25^{\prime} 46.15^{\prime \prime} \mathrm{N}$ and longitude: $87^{\circ} 6^{\prime} 50.30^{\prime \prime} \mathrm{E}$

\begin{tabular}{|c|c|c|c|c|}
\hline \multirow[b]{2}{*}{ Observer } & \multicolumn{2}{|c|}{$\begin{array}{l}\text { Maximum depth of water } \\
\text { in wetland in monsoon } \\
\text { season }(\mathrm{ft})\end{array}$} & \multirow{2}{*}{$\begin{array}{l}\text { Minimum depth of } \\
\text { water in wetland during } \\
\text { post-monsoon season }(\mathrm{ft})\end{array}$} & \multirow[b]{2}{*}{ Remarks } \\
\hline & Flood year & Normal year & & \\
\hline 01 & $17-20$ & $10-12$ & $2-3$ & \multirow{10}{*}{$\begin{array}{l}\text { Data/information was collected from the } \\
\text { different groups of people in Nagrah } \\
\text { village residing nearby wetland }\end{array}$} \\
\hline 02 & - & 12 & 2 & \\
\hline 03 & $15-20$ & $7-12$ & 2 & \\
\hline 04 & 17 & $7-12$ & 5 & \\
\hline 05 & 17 & 10 & 4 & \\
\hline 06 & $15-17$ & $7-10$ & $3-5$ & \\
\hline 07 & 15 & $7-10$ & 5 & \\
\hline 08 & - & 12 & $3-4$ & \\
\hline 09 & - & $10-12$ & $2-3$ & \\
\hline Average & 17 & 10 & 3 & \\
\hline
\end{tabular}

Note: People expressed water depths in terms of feet, so the values in the table are represented in same units. 
main channel and flood plain was dry with partial vegetation on it. It was found that the wetland bed is composed of silty clay. During the survey, we approached the local people living nearby the wetlands to inquire about the response of the wetland for varying flood pulses in the nearby Kosi river. It was clear from the discussion that wetlands were formed in monsoon season and gradually dry up in the non-monsoon season. The gradual discharge of flow from wetland to river and wetland with no connectivity was also observed in the field. Table A1 represents the minimum and maximum depth of water in the wetland during different seasons collected from various local people in Nagrah village. Table A1 clearly indicates that the water depth variation in wetland during monsoon season was between 10 and $17 \mathrm{ft}$, i.e., $3-5 \mathrm{~m}$, and in post-monsoon season, it was about $4 \mathrm{ft}(1.2 \mathrm{~m})$. Water depth in the wetland was also measured at different points along the longitudinal direction and the average depth was found to be $0.85 \mathrm{~m}$.

The experience of extreme floods was shared by the local people, which occurred during the period of 1980s, 1990s and in recent years 2002 and 2003. They described that during the flood, these wetlands play an important role by gaining water from the river and act as a buffer for excess water. Wetlands were found to be integral part of the society living nearby. People were using water for multiple purposes such as irrigation (corn fields), domestic needs, livestock consumption (cattle and goat) and other household-related works. It is also a major source of income through fishing activity for the nearby people. The field cum interaction-based survey provided vital information in understanding the behaviour of wetland in terms of depth during monsoon and beginning of the post-monsoon season. The livelihood dependence of the people from the wetland was also observed in various ways.

\section{References}

Alsdorf D E 2003 Water storage of the central Amazon floodplain measured with GIS and remote sensing imagery; Ann. Assoc. Am. Geogr. 93(1) 55-66.

Barkau R L 1987 A mathematical model of unsteady flow through a dendritic network; PhD Dissertation, Department of Civil Engineering, Colorado State University, Ft. Collins, CO.

Birkett C M 1995 The contribution of TOPEX/POSEIDON to the global monitoring of climatically sensitive lakes; J. Geophys. Res.: Oceans (1978-2012) 100(C12) 2517925179.
Birkett C M 1998 Contribution of the TOPEX NASA radar altimeter to the global monitoring of large rivers and wetlands; Water Resour. Res. 34(5) 1223-1239.

Chakraborty T, Kar R, Ghosh P and Basu S 2010 Kosi megafan: Historical records, geomorphology and the recent avulsion of the Kosi River; Quat. Int. 227(2) 143160.

Chander S, Ganguly D, Dubey A K, Gupta P K, Singh R P and Chauhan P 2014 Inland water bodies monitoring using satellite altimetry over Indian region; Int. Arch. Photogramm. Remote Sens. Spat. Inf. Sci. $\mathbf{4 0}(\mathbf{8})$ 1035.

Chow V T, Maidment D R and Mays L W 1988 Applied hydrology; McGraw-Hill, New York.

Crétaux J-F, Jelinski W, Stéphane C, Kouraev A, Vuglinski V, Bergé-Nguyen M and Gennero M-C et al. 2011 SOLS: A lake database to monitor in the near real time water level and storage variations from remote sensing data; Adv. Space Res. 47(9) 1497-1507.

Duan Z and Bastiaanssen W G M 2013 Estimating water volume variations in lakes and reservoirs from four operational satellite altimetry databases and satellite imagery data; Remote Sens. Environ. 134 403-416.

Dubey A K, Gupta P, Dutta S and Kumar B 2014 Evaluation of satellite-altimetry-derived river stage variation for the braided Brahmaputra River; Int. J. Remote Sens. 35(23) 7815-7827.

Dubey A K, Gupta P, Dutta S and Singh R P 2015a Water level retrieval using SARAL/AltiKa observations in the Braided Brahmaputra river, Eastern India; Mar. Geod. 38(Suppl 1) 549-567.

Dubey A K, Gupta P K, Dutta S and Singh R P 2015b An improved methodology to estimate river stage and discharge using Jason-2 satellite data; J. Hydrol. 529 1776-1787.

Frappart F, Seyler F, Martinez J M, Leon J G and Cazenave A 2005 Floodplain water storage in the Negro River basin estimated from microwave remote sensing of inundation area and water levels; Remote Sens. Environ. 99(4) 387399.

Frappart F, Minh K D, L'Hermitte J, Cazenave A, Ramillien G, Le Toan T and Mognard-Campbell N 2006 Water volume change in the lower Mekong from satellite altimetry and imagery data; Geophys. J. Int. 167(2) 570-584.

Frappart F, Papa F, Güntner A, Susanna W, Ramillien G, Prigent C, Rossow W B and Bonnet M P 2010 Interannual variations of the terrestrial water storage in the Lower Ob'Basin from a multisatellite approach; Hydrol. Earth Syst. Sci. Discuss. 14(12) 2443-2453.

Frazier P, Page K, Louis J, Briggs S and Robertson A I 2003 Relating wetland inundation to river flow using Landsat TM data; Int. J. Remote Sens. 24(19) 3755-3770.

Getirana A C, Bonnet M P, Calmant S, Roux E, Rotunno Filho O C and Mansur W J 2009 Hydrological monitoring of poorly gauged basins based on rainfall-runoff modeling and spatial altimetry; J. Hydrol. 379(3-4) 205-219.

Gupta P, Dubey A K, Goswami N, Singh R P and Chauhan P 2015 Use of SARAL/AltiKa observations for modeling river flow; Mar. Geod. 38(Suppl 1) 614-625.

Junk W, Bayley P B and Sparks R E 1989 The flood pulse concept in river-floodplain systems; In: Proceedings of the international large river symposium (LARS) (ed.) 
Dodge D P, Canadian Special Publication of Fisheries and Aquatic Sciences, Vol. 106, pp. 110-127.

Karim F, Kinsey-Henderson A, Wallace J, Arthington A H and Pearson R G 2012 Modelling wetland connectivity during overbank flooding in a tropical floodplain in north Queensland, Australia; Hydrol. Process. 26(18) 2710-2723.

Karim F, Kinsey-Henderson A, Wallace J, Godfrey P, Arthington A H and Pearson R G 2014 Modelling hydrological connectivity of tropical floodplain wetlands via a combined natural and artificial stream network; Hydrol. Process. 28(23) 5696-5710.

Koblinsky C J, Clarke R T, Brenner A C and Frey H 1993 Measurement of river level variations with satellite altimetry; Water Resour. Res. 29(6) 1839-1848.

Leon J G, Calmant S, Seyler F, Bonnet M P, Cauhopé M, Frappart F and Fraizy P 2006 Rating curves and estimation of average water depth at the upper Negro River based on satellite altimeter data and modeled discharges; J. Hydrol. 328(3-4) 481-496.

Papa F, Prigent C, Durand F and Rossow W B 2006 Wetland dynamics using a suite of satellite observations: A case study of application and evaluation for the Indian Subcontinent; Geophys. Res. Lett. 33(8).

Papa F, Durand F, Rossow W B, Rahman A and Bala S K 2010 Satellite altimeter-derived monthly discharge of the Ganga-Brahmaputra River and its seasonal to interannual variations from 1993 to 2008; J. Geophys. Res.-Oceans 115(C12).

Roux E, Cauhope M, Bonnet M P, Calmant S, Vauchel P and Seyler F 2008 Daily water stage estimated from satellite altimetric data for large river basin monitoring/estimation de hauteurs d'eau journalières a partir de données d'altimétrie radar pour la surveillance des grands basins fluviaux; Hydrol. Sci. J. 53(1) 81-99.
Shiklomanov A I, Lammers R B and Vörösmarty, C J 2002 Widespread decline in hydrological monitoring threatens Pan-Arctic research; EOS Trans. Am. Geophys. Union $\mathbf{8 3}$ $13-16$.

Siddique-E-Akbor A H M, Hossain F, Lee H and Shum C K 2011 Inter-comparison study of water level estimates derived from hydrodynamic-hydrologic model and satellite altimetry for a complex deltaic environment; Remote Sens. Environ. 115(6) 1522-1531.

Sinha R 2008 Kosi: Rising waters, dynamic channels and human disasters; Economic and Political Weekly, pp. 4246.

Sinha R, Sripriyanka K, Jain V and Mukul M 2014 Avulsion threshold and planform dynamics of the Kosi River in north Bihar (India) and Nepal: A GIS framework; Geomorphology 216 157-170.

Stokstad E 1999 Scarcity of rain, stream gages threatens forecasts; Science $\mathbf{2 8 5} 1199$.

Verron J, Bonnefond P, Aouf L, Birol F, Bhowmick S A, Calmant S, Conchy T, Crétaux J F, Dibarboure G, Dubey A K and Faugère Y 2018 The benefits of the Ka-band as evidenced from the SARAL/AltiKa altimetric mission: Scientific applications; Remote Sens. 10(2) 163.

Wen L, Macdonald R, Morrison T, Hameed T, Saintilan N and Ling J 2013 From hydrodynamic to hydrological modelling: Investigating long-term hydrological regimes of key wetlands in the Macquarie Marshes, a semiarid lowland floodplain in Australia; J. Hydrol. 500 45-61.

Zhang J, Xu K, Yang $\mathrm{Y}$, Qi L, Hayashi $\mathrm{S}$ and Watanabe M 2006 Measuring water storage fluctuations in Lake Dongting, China, by Topex/Poseidon satellite altimetry; Environ. Monit. Assess. 115(1-3) $23-37$. 